\title{
Making Sense of What We Are: A Mythological Approach to Human Nature
}

\author{
MICHAEL HAUSKELLER
}

\begin{abstract}
The question what makes us human is often treated as a question of fact. However, the term 'human' is not primarily used to refer to a particular kind of entity, but as a 'nomen dignitatis' - a dignity-conferring name. It implies a particular moral status. That is what spawns endless debates about such issues as when human life begins and ends and whether human-animal chimeras are "partly human". Definitions of the human are inevitably "persuasive". They tell us about what is important and how we should live our lives as humans, and thus help us to make sense of what we are.
\end{abstract}

"What's in a name? That which we call a rose

By any other name would smell as sweet."

William Shakespeare, Romeo and Fuliet II, ii, 1-2

Human variation is an undeniable fact. Everybody is different from everybody else. There are no two persons in this world that are completely alike. Nor, however, are they completely different. So for any two persons there are dissimilarities and similarities between them. We acknowledge the fundamental dissimilarity by regarding and treating them as different individuals, and we acknowledge the fundamental similarity by regarding and treating them both as human beings. Of course there may be other similarities, for instance they might be both female or both male, both light skinned or both dark skinned, both blue-eyed or both brown-eyed, but in most contexts and for most purposes (not in all, though) the most relevant similarity between them consists in their both being human. Under normal circumstances we have no difficulty to recognize each other as human and to tell humans and non-humans apart. This suggests that we must have some idea, however vague, of what makes a thing human. However, this idea may not always be the same. Perhaps 


\section{Michael Hauskeller}

there was a time when white people weren't sure whether black people were human at all (and vice versa). And perhaps we will soon enhance or change human beings in such a way that, after an initial phase of doubting whether the resulting beings are still human, we will not only accept them as human but will gradually come to see them as paradigmatically so. This could mean that what presently counts as human will be regarded as merely subhuman or pre-human.

Now if that were to happen would we then be justified in saying that this new race of people was wrong to regard themselves as human and us as subhuman or pre-human? Or would they be justified in saying that we were wrong to regard ourselves as human? Could someone who is neither one of us nor one of them (say, a scientist from another planet) decide who is right and who is wrong? The answer is of course no, they couldn't. All that could be stated is that on the basis of our own understanding of what it means to be human we are clearly human, and on the basis of their understanding of what it means to be human we seem to be not, or not entirely. In order to declare one of these contrasting understandings wrong we would have to assume that the words we use always refer to the same basic property that makes a thing what it is, even when we have no idea what this property is and consequently never think of it when we use the term. In other words, we would have to assume that what we think a term means and how we in fact use it is one thing and what it really means and how it ought to be used quite another thing. Yet this assumption is hardly plausible. As individuals we can of course be mistaken about the meaning of a certain term. I could, for instance, mistakenly believe that the word 'pedestrian' refers to an adult male who has sexual relations with young boys, and use it accordingly. I would then be clearly wrong but only because this is not the way the word is normally used, that is by the vast majority of speakers. We can all be wrong by violating the meanings established by a speech community, but the speech community itself can never be wrong because it defines, through the shared practice of speaking and writing, the very meaning of the words that individual speakers use.

The word 'human' is no exception. As far as essence goes, the only essence we can ever hope to be relatively sure of is what John Locke called the nominal essence. ${ }^{1}$ Even if human beings had a "real essence" whereby they are what they are and whereupon their

1 John Locke, An Essay Concerning Human Understanding, in The Works of John Locke. A New Edition, Corrected. In Ten Volumes, vol. II, London 1823, bk. 3, ch. 3, par. 15 . 


\section{A Mythological Approach to Human Nature}

discoverable qualities depend, and even if we discovered this essence one day (neither of which is very likely), then we would have not much use for it because it would either be in accordance with the nominal essence of humanity, that is, with the abstract idea to which we attach the general name 'human being', in which case we would not have learned anything new, or it would conflict with it, in which case we would not be willing to accept it. What we mean by the term 'human' is not some hidden property in virtue of which we are what we are - Locke's real essence - but a loosely connected cluster of recognizable properties - Locke's nominal essence: "to be a man, or of the species man, and have the essence of a man is the same thing. Now since nothing can be a man, or have a right to the name man, but what has conformity to the abstract idea the name man stands for; nor any thing be a man, or have a right to the species, but what has the essence of that species; it follows that the abstract idea for which the name stands, and the essence of the species, is one and the same." 2

Yet ideas change, and not least our ideas about what it means to be human, which means that the (nominal) essence of humanity also changes over time. Human nature then is constantly in a state of flux. From this it follows that if two speech communities do not use the term 'human' in the same way then neither of them is right and neither wrong.

However, we may still want to insist that whether or not black people are classified as human, or we are all classified as subhuman by future generations, is more than just a matter of linguistic convention. It shouldn't matter how we classify, what we call human and what not, but to many people it obviously does. Why is that so? Why do we care whether we are human or not, or someone else is? And why do we care what makes us human, that is, why do we care for the reason we call ourselves human? I think the answer to the first question (and thus, as we will see, also to the second) is that 'human', to us, is usually more than just a descriptive predicate. It more often than not has a very strong prescriptive dimension. It is, just as the word 'person' according to St Thomas Aquinas, a nomen dignitatis, that is a title of honour, or a dignity-conferring name. ${ }^{3}$ Shakespeare's Juliet might have been right about roses, but that which we call a human, by any other name would normally not smell as sweet. I am not saying that this is necessarily so. I am

Ibid., par. 12.

Thomas Aquinas, Scriptum super Sententiis, lib. 1, dist. 10, q. 1, a5: "Persona est nomen dignitatis." 


\section{Michael Hauskeller}

happy to concede that the term 'human' can perhaps be used in a purely descriptive way, but my point is that this is not the way it is normally used. When it comes to applying the term 'human' to an entity, we have obvious difficulties to separate the descriptive from the prescriptive. It is the same kind of difficulty that arises with respect to the term 'art', which is also (often used as) a nomen dignitatis. The puzzled question 'But is it art?' that many people can't help asking when being confronted with contemporary art clearly reflects their expectation that art should be something intrinsically valuable, worthy of being looked at, thought about, and being created in the first place. Thus 'Is it art?' usually means something like 'Is it any good?' But it is not so much that we are unable to distinguish properly between the descriptive and the prescriptive but rather that we are deeply reluctant to use the term in a purely descriptive manner. It would in fact be very easy to provide a definition of art if we could only bring ourselves to ignore the prescriptive aspect all together. 'Art is everything that is regarded as art by at least one person who doesn't know the artist personally' is a perfectly good definition, but it is very unsatisfactory nonetheless because it doesn't give any indication why we should care for art. And that we should care is part of what we mean when we call something art.

Now, with respect to the human we have a similar reluctance to accept a purely descriptive definition. Questions such as 'When does human life begin?' and 'When does human life end?' are hotly debated. People clearly believe that it makes a huge difference in practical terms whether we say that human life begins with conception or that it begins with birth. Likewise, people believe that it makes a difference whether we say that human life ends with the irreversible termination of electrical activity in the neo-cortex, the irreversible termination of all brain activity, or the irreversible termination of all bodily metabolic processes (heart-beat and respiration). The reason for this is obvious: we tend to treat what we think of as humans in a way that is markedly different from the way we treat what we think of as non-humans (including not-yet-humans and no-longerhumans). And we reflect this experienced and expected treatment in our use of the word 'human'. When someone says that human life begins with conception they usually mean to say that it is morally questionable to destroy a human embryo even at a very early stage of its development. Conversely, when someone insists that human life, or more precisely the life of a human being, does not begin before birth, they usually take this to mean that abortion is justified or is at least not morally equivalent to killing a human being. 


\section{A Mythological Approach to Human Nature}

Equally hotly debated, and for similar reasons, are questions about the status of human-animal chimeras and hybrids. Is for instance a human-mouse chimera, that is, a mouse that contains some cells with human DNA, "partly human"? The answer depends on whether or not we think that our being human is a result of our genes, in the sense that this is "what makes us human", as James Watson once proclaimed. ${ }^{4}$ But why should we care whether what technically speaking and from a biological standpoint is a humanmouse chimera is, or is not, classified as partly human? The answer is that being human, and perhaps even being 'partly human', is associated with a particular moral status that is deemed considerably higher than the moral status of non-humans. Accordingly, a problem seems to arise as to how we should treat "partly human" mice: the same way as other mice, or like human beings, or something in between - better than other mice although not quite like human beings? As the Scottish Council on Human Bioethics warned in a report issued in 2006, "if an entity is accepted as having been created by human and non-human beings, then its whole identity and its entitlement to human rights and dignity could be challenged." 5 The reason for this is that the name 'human' carries considerable moral weight, so that we cannot call certain transgenic mice "partly human" without thereby suggesting that they have a higher moral status than other, 'normal' mice.

This persuasive power of the term 'human' is the reason why it does not only matter what is being called human and what not, but also how we justify applying, or denying, the term to an entity, or generally speaking how we define being human. 'Human' is one of those terms that, in the words of C.L. Stevenson, have "both a

4 Quoted in Dorothy Nelkin and Susan Lindee, The DNA Mystique: The Gene as a Cultural Icon (New York: Freeman, 1995), 40. For a similar view see John Noonan, 'An Almost Absolute Value in History', in: Lewis M. Shwartz, Arguing About Abortion (Belmont, CA: Wadsworth, 1993), 59.

Scottish Council on Human Bioethics, 'Embryonic, Fetal and Post-natal Animal-Human Mixtures: An Ethical Discussion', Human Reproduction and Genetic Ethics 12/2 (2006), 35-60. A similar concern was raised by Jason S. Roberts and Francoise Baylis, 'Crossing Species Boundaries', The American Fournal of Bioethics 3/3 (2003), 1-13: "All things considered, the engineering of creatures that are part human and part nonhuman animal is objectionable because the existence of such beings would introduce inexorable moral confusion in our existing relationships with nonhuman animals and in our future relationships with past-human hybrids and chimeras." 


\section{Michael Hauskeller}

vague conceptual meaning and a rich emotive meaning" and whose conceptual meaning "is subject to constant redefinition." 6 It invites such redefinition precisely because of its rich emotional meaning that is an ideal vehicle for advocating one's own ideas of what being human is about, what humans should be like and how they should lead their lives, and for inserting these ideas into the very meaning of the word. "The words are prizes which each man seeks to bestow on the qualities of his own choice." 7 Stevenson points out that defining such a word is a way of redirecting interests. Each definition draws our attention to a particular aspect of the word or object that is meant to be defined and confers its emotional value upon this aspect. "Which meaning we choose, however, is no trivial matter; for we shall dignify that meaning by a laudatory title. To choose a meaning is to take sides in a social struggle." ${ }^{\text {I }}$ want to propose here that definitions of the human are as a rule, in Stevenson' sense, “persuasive definitions", that is definitions that give "a new conceptual meaning to a familiar word without substantially changing its emotive meaning, and which is used with the conscious or unconscious purpose of changing, by this means, the direction of people's interests." 9

Definitions can obviously have different purposes, but it seems that independent of the purpose of defining 'humanness' the ideal definition should refer to a property that is universal (so that all humans have it) and uniquely characteristic of humans (so that no non-human has it). Unfortunately, such a property is hard to find. As David Hull has pointed out, in "most cases, any character universally distributed among the organisms belonging to a particular species is also possessed by organisms belonging to other species; and conversely, any character that happens to be limited to the organisms belonging to a particular species is unlikely to be possessed by all of them."10 Biological species are characterised by their very

6 Charles Leslie Stevenson, 'Persuasive Definitions', 333, Mind 47 (1938), 331-350.

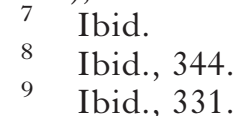

10 David Hull, 'On Human Nature', 383, in: The Philosophy of Biology, eds. David Hull and Michael Rose (Oxford: Oxford University Press 1998), $383-397$. 
variability, without which they could not evolve. Yet they do evolve, which makes it even more unlikely that we will find a characteristic that all humans and only humans at all times throughout the history of the species possess. It appears entirely impossible when we remember that, properly speaking, there is no such thing as the "history of the species", because there is no point in time where a particular species begins to exist and another point in time where it ceases to exist. The process of evolution knows no species boundaries. One species evolves into another without clear dividing lines. It follows, again, that if we are looking for a definition of the human we must confine ourselves to the present and to what or who belongs to the human species (understood as a mating and reproduction network ${ }^{11}$ ) now. If we do that and we try hard enough, we may come up with a property that only humans have. ${ }^{12}$ The trouble is that this property might not strike us as particularly relevant. James Boswell, Samuel Johnson's biographer, once proposed (perhaps jokingly, but with Boswell you never know) to define man as a "cooking animal", reasoning that the "beasts have memory, judgment and all the faculties and passions of our mind, in a certain degree; but no beast is a cook." 13 This definition can of course be repudiated for neglecting the fact that not all humans can cook (a defect that is particularly common among males), but in that respect Boswell's definition is no worse than many other definitions of the human that have been widely accepted and promoted for millennia, such as Aristotle's definition of the human as a zoon logon echon, or rational (reason and language having) animal. Clearly not all of those who are biologically human are rational, or at least not more rational than some animals, and even the best of us are only partly rational and often enough decidedly irrational. Yet Aristotle's definition has been cited approvingly countless times

\footnotetext{
11 Ibid., 384.

12 For the purpose of the argument, I am assuming here that being human and belonging to a particular biological species is co-extensive in the sense that if you are human then you belong to that species, and if you belong to it then you are human. However, we can imagine that the species evolves in such a way that it splits into two groups whose members can no longer reproduce with members of the other group. We would then have two biological species, but there is no reason why we shouldn't regard the members of both of them as equally human.

13 James Boswell, Fournal of a Tour to the Hebrides with Samuel Fohnson, LL.D., ed. R.W. Chapman (London, 1924), 179, fn. 1.
} 


\section{Michael Hauskeller}

whereas Boswell's would convince no one but perhaps a chef. ${ }^{14}$ Why is that so? The real problem with Boswell's definition is not that it is not universal enough but that it fails to highlight a property that can plausibly be understood as giving us that special worth that the attribute 'human' seems to indicate.

The failure to lend support to this alleged worth is also the problem with Plato's famous definition of the human as a featherless twolegged being, which in itself may very well meet the requirements of a good definition. Perhaps all humans are indeed featherless and two-legged and perhaps no animal is. The cock that Diogenes, the cynic, plucked and presented as "Plato's human"15 presents no counter-example precisely because it first had to be plucked. But even if there were in fact other naturally featherless two-legged animals - animals that we would hesitate to call human - , we might be the only ones. If we are, then Plato's definition of the human as a featherless two-legged being is as good as any other when it comes to finding a criterion to distinguish this particular kind of being from all other beings. Why then does it strike us as off the point, even as ridiculous? Because we usually demand more of a definition when we ask what a particular thing is. We want the definition to focus on what is essential about the defined. Yet how do we distinguish the essential from the non-essential? Why shouldn't featherless two-leggedness be considered essential? I think that the main reason for this is that Plato's definition fails to capture the emotional significance conveyed by the term 'human'.

Every seriously proposed definition of the human entails and promotes some opinion about how humans should, and should not, be like. They are meant to persuade to a particular way of living. When we define ourselves with Aristotle as rational animals, or as political animals, we do not so much describe what we are, or what we think we are, but rather what we think we ought to be, or ought to aspire to be. The definition proposes an ideal of humanity that every individual human is called upon to validate. We can of course be irrational and we can, if we really want to, live in solitude and be unconcerned about human relations, but the definition will tell us that this is not how we ought to live. We are told that being rational, or living and working for the community in the polis, is what being

14 I am, of course, exaggerating. There are sociologists who do take Boswell's apercu quite seriously. See for instance Michael Symons, $A$ History of Cooks and Cooking (Urbana/Chicago, 2000).

15 Diogenes Laertius, Lives of Eminent Philosophers (London: William Heinemann/Cambridge, MA: Harvard University Press, 1958), VI 40. 


\section{A Mythological Approach to Human Nature}

human is all about, and only if we view ourselves in this way and act accordingly we are human in the full sense of the word. Thus defining the human is always an attempt at defining the truly human. The definition is descriptive, but since what it describes is the truly human, which as a rule contrasts with the actually existing human, it is also prescriptive. Sometimes it is even entirely prescriptive. Immanuel Kant thought that what makes us human is not rationality but auton$o m y$, that is the ability to act from duty, i.e., purely out of respect for the moral law. However, he also declared that we cannot know whether there ever was, or ever will be, a human being that really acts autonomously. There may always be an ulterior motive, even when we sincerely believe that we act from duty alone. Yet even if humans might in fact be not autonomous, autonomy is still the hallmark of humanity. Kant's whole moral philosophy grounds in this paradigmatically persuasive definition.

The contrast between what humans actually are like and what, by virtue of their humanity, they should be, is also central to those definitions of the human that seem to draw a more realistic picture by focusing on the deplorable facts of human life. When Jonathan Swift redefines the human through the eyes of his Gulliver as a nasty, ugly, and brutish Yahoo, he forces his readers to look into a mirror in which they see themselves as they have never seen themselves before, showing them how far they are still away from realizing the ideal and becoming truly human. Even Plato's seemingly silly definition of the human as a featherless two-legged animal can be seen in this light and used for expressing a notion of ideal humanness. Thomas Carlyle for instance repeatedly used it to express his contempt for a particular but very common type of human. In a letter to John Ferguson, dated 22 October 1820, Carlyle reports that he had been asked to work as a tutor for a young boy, but when he got there he found that the boy was "a dotard, a semi-vegetable" and his "elder brother, head of the family, a two-legged animal without feathers, intellect, or virtue" with the "power of eating pudding, but no higher power." 16 And in his early novel Sartor Resartus he mocks that in the midst of human misery and violence more than "five hundred thousand two-legged animals without feathers lie round us, in horizontal positions; their heads all in night caps, and full of the foolishest dreams." 17 This latter remark comes very close to a statement about human nature in general.

16 The Collected Letter of Thomas and Fane Welsh Carlyle, Vol. 1, (Durham, NC, 1970), 285.

17 Thomas Carlyle, Sartor Resartus (Everyman's Library, London, 1908), 16. 


\section{Michael Hauskeller}

Yet all this pessimism about human nature does not in the least affect the ideal. On the contrary, it only serves as a reminder of the ideal and encourages us to renew our efforts to get close to it. Perhaps most people are in fact nothing more than two-legged animals without feathers that specialise in pudding-eating, but they shouldn't be. There is (or should be) more to being human than that. Accordingly, when Prendick, the narrator of H.G. Wells's The Island of $\mathrm{Dr}$ Moreau finally returns home and finds human company almost intolerable because he cannot help seeing the people around him as similar to the Beast People of Moreau's island, "animals half-wrought into the outward image of human souls," 18 he has lost his faith in humanity but clearly has not given up his ideas about what it means to be (truly) human. He sees "faces keen and bright, others dull and dangerous, others unsteady, insincere; none that have the calm authority of a reasonable soul." The reasonable soul is what humans are supposed to have. It is the kind of soul that distinguishes them from animals. Because it is a human proprium, or rather the human proprium, it is proper for humans to be equipped with such a soul. Yet as it is, most humans bear only "the outward image of human souls" without actually having one. Prendick's reflections lead us back to the simile for the human soul that Socrates proposes at the end of Plato's Republic. There we are asked to imagine the soul as a combination of three different entities: a giant multi-headed beast, a lion, and a human being, all bound together and furnished with the outward frame of a human being. ${ }^{19}$ Only, explains Socrates, when the inner human being rules with the help of the lion over the multi-headed beast, then what appears to be human from the outside is also human from the inside. Then the Yahoo really becomes what he looks like to the casual observer: a human being. But in order for that to happen a lot of work needs to be done.

The underlying notion of an ideal humanness, together with the pessimistic assessment that humanity, as it presently is, still has a long way to go to reach this ideal, points away from the present and towards a possible (and desirable) future actualization of whatever is proposed as the defining aspect of our humanity. Hence definitions of the human, whether they highlight a desirable and supposedly dignity-conferring property like rationality or autonomy or, to the contrary, a property that makes us ashamed of how we behave most

18 H.G. Wells, The Island of Dr. Moreau (London: Heinemann 1921), 173.

Plato, Republic, 588 c-e. 
of the time, often have a decidedly utopian character. Definitions of human nature are miniature utopias: they indicate a place that does not (yet) exist but that might and should exist in future. Thus, ironically, the hypothetical future race of enhanced humans that I mentioned at the beginning of this paper could base their claims to being the first true humans on our own definitions of humanness. They can claim to actually be what we only pretend to be or flatter ourselves to be. They can claim to be what Diogenes, the cynic the same one that made fun of Plato - , was looking for when he lit a candle in daylight and on being asked what he was doing replied that he was looking for a human being. ${ }^{20}$

\section{(3)}

There are various, equally valid ways we can define ourselves. We can see ourselves primarily as rational beings, images of God, speaking, knowledge-seeking, art-producing, story-telling, tool-making, grave-digging, symbolizing, lying, laughing and crying, or selfdesigning beings, mortal or potentially immortal beings, natural or (partly) supernatural or "transanimal" beings. ${ }^{21}$ Not all of these properties are defining in the strict sense. Claims about human nature can either be about what is specifically human or what humans may share with other beings, e.g. mortality. We can say that mortality is part of human nature despite the fact that all living beings are mortal, in the sense that it is essential for the way we are and see ourselves as human beings, so that an immortal human being would no longer be a human being at all. Alternatively, one could argue that in fact only humans are mortal in the sense that only they (although again probably not all of them) are aware of their mortality. As JL Borges once remarked: "To be immortal is commonplace; except for man, all creatures are immortal, for they are ignorant of death." 22 Yet whatever property we emphasise, whatever property, or complex of properties, we declare to be essential, our choice will make a difference also in practical terms. It will, as Stevenson said, redirect people's interests, or is at least intended to do so. And we want our interests to be directed when we seek a

20 Diogenes Laertius, loc. cit., VI 41.

21 Cf. Hans Jonas, 'Werkzeug, Bild und Grab', in Scheidewege 15 (1985/86), 85-112.

22 Jorge Luis Borges, Labyrinths (New York: New Directions Publishing, 1962), 114. 


\section{Michael Hauskeller}

definition of humanness. We want to know what we are mainly in order to know what kind of life is the right one for beings such as us. We ask what it means to be human in order to find out what it means to be a good human. We seek to define ourselves, give ourselves an identity, and then try to be what we tell ourselves we are. The common and seemingly factual disagreement about what it means to be human is thus only the expression of a deeper disagreement about what the best way of being in the world as a human is. When we embrace a particular conception of human nature we implicitly make a statement about what, in our view, human life is or should be all about, what matters or should matter in life, and what makes a human life good. In that sense, human nature is a myth, by which I don't mean that there is nothing that all humans and only humans have in common, but rather that each attempt at defining what we are is the telling of a story that implicitly or explicitly claims to be of prime significance for the way we ought to lead our lives. To a certain degree all philosophies tell a story: about what it means to be human, about what is worth doing, desiring, ${ }^{23}$ and fighting for, about good and evil and what life is all about. But the storytelling is most evident, or most concentrated, in claims about human nature.

In an article entitled 'Science and Myth', John Maynard Smith points out that an important function of myths is to "give moral and evaluative guidance" and to provide "a source and justification for values", and that people repeat myths "because they hope to persuade others to behave in certain ways." 24 Definitions of the human are clearly myths in that sense. They are persuasive definitions that are meant to, and are taken to, provide moral guidance and justification for values, and they recommend that we behave in certain ways. Occasionally this is openly acknowledged. Edward O. Wilson for instance, the notorious champion of socio-biology or evolutionary psychology, admits in his book On Human Nature that scientific materialism is nothing but a mythology, ${ }^{25}$ although he insists that

23 Cf. Northrop Frye, Anatomy of Criticism (Princeton, JJ: Princeton University Press, 1957), 136: "In terms of narrative, myth is the imitation of actions near or at the conceivable limits of desire. (...) The fact that myth operates at the top level of human desire does not mean that it necessarily presents its world as attained or attainable by human beings."

24 John Maynard Smith, 'Science and Myth', 375 and 381, in: David L. Hull and Michael Ruse (eds.), The Philosophy of Biology (Oxford: Oxford University Press 1998), 374-382.

25 Edward O. Wilson, On Human Nature (Cambridge, MA/ London: Harvard University Press, 1978), 201. 


\section{A Mythological Approach to Human Nature}

it is a particularly powerful one because it "is the only mythology that can manufacture great goals from the sustained pursuit of pure knowledge." 26

Incidentally, Wilson is one of those who believe that we can learn more about human behaviour, that is, why we do what we do, by looking at animal behaviour. This approach is thought to be justified by evolutionary theory. If the theory is right then our behaviour must have evolved, which is taken to mean that it was naturally selected by virtue of its survival value. ${ }^{27}$ This, however, might not be obvious anymore since today we live in a cultural setting that renders useless certain behaviour patterns that once might have been highly useful. Since our modern culture is, in evolutionary terms, very young, and our genetic composition, in which our behaviour is rooted, does not change that fast, we find ourselves behaving in a way that often seems to make no sense. Looking at analogous behaviour patterns in animals might then help us discover reason in the seemingly unreasonable by helping us understand why we do what we do. Understanding is important because only when we understand and acknowledge the powers that have shaped us we can hope to deal with them effectively. As Wilson says: "The learning rules of violent aggression are largely obsolete. We are no longer huntergatherers who settle disputes with spears, arrows, and stone axes. But to acknowledge the obsolescence of the rules is not to banish them. We can only work our way around them." 28 This implies, of course, that we can work our way around them. We are not slaves to our genes in the sense that we cannot escape the behaviour patterns that we have inherited from our evolutionary ancestors. Often, however, evolutionary psychologists like Wilson are attacked for allegedly turning us into genetically determined natural automata, thereby denying human freedom of will and dignity and justifying political inequality, racism, rape and several other morally obnoxious human dispositions. Even the title of Wilson's book, On Human Nature, provokes resentment because it underlines the sociobiological definition of the human as a natural being: an animal that differs in many ways from other animals, but an animal

26 Ibid., 207.

27 That this is at best only half of the truth and rests on a certain very questionable interpretation of the theory is pointed out by various critics, for instance by Philip Kitcher, Vaulting Ambition (Cambridge, MA, London: MIT Press, 1985), or John Dupre, Human Nature and the Limits of Science (Oxford: Clarendon Press, 2001).

28 Ibid., 119. 


\section{Michael Hauskeller}

nonetheless. To some people the expression 'human nature' feels like an oxymoron, that is, a contradiction in terms, like 'dry water' or 'Christian science'. That is because the word 'nature' is regarded as signifying confinement, necessity, inevitability. In this sense, nature begins where human control ends. So if one believes that humans are basically free to do whatever they want to, all talk of "human nature" is inherently suspicious. However, denying human nature (in a narrow sense) is of course also a statement about human nature (in the wider sense). It is a different story that we tell about ourselves, a different way of making sense of what we are. To declare, as Pico della Mirandola did, ${ }^{29}$ that humans have no nature, thus entails a positive claim about human nature. Put paradoxically, we could say that it is our nature to have no nature, and consequently, that we are nature-less animals or beings. This of course has also implications for human practice. In Pico's case it was the claim that, since there are no natural boundaries to our being, we ought to take our destiny in our own hands and design ourselves. This claim is echoed by proponents of human enhancement today. Gregory Stock for instance, a prolific advocate of biotechnology and human self-design, demands that we "seize control of our evolutionary future" and thinks that the "age of human self-design" has already begun. ${ }^{30}$

Others, like the anthropologist Jonathan Marks, seem to oppose the socio-biological naturalisation of the human because they fear the false moral conclusions that might be drawn from it. ${ }^{31}$ Marks argues that humans are essentially cultural beings, so that we cannot learn anything from looking at animals or so called primitive humans that live in an allegedly more natural setting. Humans, no matter where they live and how they live, are all equally cultural beings, equally far removed from nature. In his view, socio-biologists construct an "evolutionary origin narrative" that is designed to justify race-based and sex-based inequalities. Biology, he emphasises, "is irrelevant to the real issue of good and bad." Of course it is, and Wilson does not deny it. He does not commit the naturalistic fallacy that Marks accuses socio-biologists of. So where is the

29 Pico della Mirandola, On the Dignity of Man, On Being and the One, Heptaplus (New York: Macmillan, 1985), 3-7. 2003), 2.

30 Gregory Stock, Redesigning Humans (London, Profile Books

31 Jonathan Marks, 'The nature of humanness', 2006 manuscript, forthcoming in Oxford Handbook of Archaelogy, ed. Cunliffe and Gosden, Oxford. 
problem? The problem is in fact the narrative that is built around (certain interpretations of) evolutionary theory - by proponents and opponents alike. If there is a problem at all, then it lies in what we make of the analogies between animal and human behaviour that socio-biologists are fond of pointing on. It all depends on whether or not we want to define ourselves as basically natural beings. So when Marks accuses socio-biologists of committing a naturalistic fallacy, he actually misses the point: biology may not be in itself relevant to what is good or bad but when it is thought relevant, then it $i s$ relevant. It is a question of finding an image of ourselves with which we can identify. To understand ourselves primarily as essentially cultural, i.e., non-natural beings, means telling, and listening to, a different narrative, but a narrative nonetheless. The socio-biological "nothing-butism" school, which according to Marks downplays or ignores what is uniquely human and "sees human behaviours as essentially unchanged ape behaviours" is a man of straw that doesn't really exist. But even if it does, then its ideological underpinning is easily matched by the ideology in Marks's own school of what might be called "nothing-likeism", which downplays and ignores what we have in common with the great apes and declares that human behaviour has got nothing whatsoever to do with animal behaviour, not even the behaviour of our closest animal relatives.

The truth about our nature is very simple (and probably very unsatisfactory). People are all different from each other, and they are also very much alike. People also differ from animals in many respects, but again in many other respects they are very similar to them. What is more important, the similarities or the dissimilarities? That depends on our interests. Nothing that we do is more natural than anything else. Nor less natural. Nothing we do is more human, or less human, than anything else. Everything we do is human, whether all humans do it or we are the only ones who do it, whether only humans do it, or animals, too. Whatever we do, we are always what we are, and we are all that we are. Hence, since all definitions are selective, no definition can capture what we are. In this sense, human nature is indefinable. Yet we may still need definitions of the human: not in order to learn what we are, but in order to make sense of it. 